\title{
STEREOTYPES IN THE PERCEPTION OF CROSS-BORDER BUSINESS PARTNERS (ON THE EXAMPLE OF PODLASIE ENTREPRENEURS)
}

\author{
ANNA TOMASZUK
}

\begin{abstract}
A B S T R A C T
The aim of the study was to determine whether the Podlasie entrepreneurs think about neighboring nations (Belarusian, Lithuanian, Ukrainian and Russian) in a stereotypical way (ascribing to them certain negative characteristic) and, if that affects in any way the decision about cooperation. The theoretical part of the article concerns the concept of stereotype, its features and functions. In the empirical part the results of research are presented. It was carried out on a group of Polish entrepreneurs (in Podlasie) in order to identify their attitudes and opinions on some neighboring nations (Russians, Belarusians, Lithuanians and Ukrainians). The research was a pilot study. The sample included two hundred entrepreneurs. Authors' questionnaire was used. In the light of the study negative national stereotypes seem to have a great importance in creating cross-border networking.
\end{abstract}

KEY WORDS

stereotype, national stereotypes, cross-border cooperation, entrepreneurs of Podlasie

DOI: 10.1515/emj-2016-0017
Corresponding author:

Anna Tomaszuk

Bialystok University of Technology, Faculty of Management, Department of Organization and Management

e-mail: a.tomaszuk@pb.edu.pl

\section{INTRODUCTION}

In recent decades, due to the continuous technological progress and increasing globalization, the number of companies and organizations operating in the markets wider than national has significantly increased (Gurgul \& Lach, 2014). We have been witnessing the globalization, which has taken different forms (Qiu, 2010). For Podlaskie Province - because of its unique location close to Belarus, Lithuania, Ukraine and Russia (Kaliningrad) - the aspect of cross-border cooperation and appropriate assessment of frontier markets is particularly important.

Border location can be seen in two levels - it is often the cause of economic underdevelopment, but it can also be a factor affecting the development, because it provides the opportunity to establish direct cooperation with neighboring regions that belong to different national space, which in turn can be an asset for cooperating regions (Mierosławska, 2004). Crossborder cooperation entails a number of challenges in the form of economic, legal and social barriers. The social barriers include negative experience from historical developments, lack of residents' psychological readiness to cooperate and differences in mentality (Pisarenko, 1998). Therefore, in order to strengthen the cooperation not only the burden of historical events, mutual prejudices and mistrust would need to be overcome, but also negative stereotypes (Soclab, 2013) which play an important role in intercultural communication (Fiske, 1988).

The article addresses the issue of stereotypes and their significance, with particular emphasis on the role of national stereotypes. The potential impact of negative national stereotypes on the possibility of creating cross-border cooperation was investigated. 
The study aimed at determining which of the selected negative features discourage entrepreneurs from cooperation and whether these features were present in respect to the nations: Belarusian, Lithuanian, Ukrainian and Russian. The research was a pilot study; the authors' questionnaire was filled in by two hundred entrepreneurs from Podlasie.

\section{SIGNIFICANCE OF STEREOTYPES}

W. Lippmann was the first one who noticed the significance of stereotypes and defined the term as "mechanisms ensuring the economy of description and perception of phenomena" (Lippmann, 1965). According to Lippman, people cannot achieve full mental representation of the outside world due to its complexity and react to it using simplified images, which are their window to the outside world (Kurcz, 1994). Stereotypes can be seen as beliefs about the attributes and behaviors of members of a social group (Hilton \& Hippel, 1996). However, due to the fact that stereotypes may also describe the differences between two or more groups, they can be seen in the context of beliefs about group differences (Biernat \& Candall, 1996; Ford \& Stangor, 1992; Martin, 1987).

Guided by stereotypes, one assigns the same features to all members of a group and saves oneself the trouble of noticing a different personality in each individual (Allport, 1954). In the early literature on the subject, stereotypes were generally condemned as excessively negative, over-generalizing and not corresponding to reality. However, in the later theories a conclusion appeared that stereotypes should not be regarded as morally evil and the people who use them should not be pointed out with an accusing finger. According to the new approach stereotypes are equated with the characteristics attributed to a particular social group without their evaluation (Stephan \& Stephan, 2007).

Literature on the subject provides hundreds of definitions of the term „stereotype" (Reszke, 1998; Spencer-Rodgers, 2001). Differences in perceptions are conditioned by, among others, the kind of scientific discipline which the author of a definition represents (Countant et al., 2001). Psychologists generally understand the stereotype as ,a schematic image of the representatives of a particular social group" (Kofta \& Sędek, 1999), which reflects the traditional approach to stereotypes in social psychology - stereotypes are treated as ,generalization relating to a group in which identical characteristics are assigned to all its members without any exceptions, regardless of the real differences between them" (Aronson et al., 1997). In the socio-cultural approach stereotypes are defined as ,a collection of information about social groups, widespread among the members of a particular culture" (Macrae et al., 1999). However, in the common usage, stereotype is a simplified, shortened picture of reality functioning in social awareness referring to groups, individuals, institutions, colored by assessment and fixed by multiple repetitions" (Smolski et al., 1999). For some time now stereotypes are treated as a kind of „cultural cliché" (Hill, 2004), reflecting well-established attitudes and prejudices with roots reaching deep into the collective subconsciousness and conducive to deepening inter-group animosities and conflicts with ethnic, racial or religious background (Gawarkiewicz, 2011).

Stereotypes arise as a result of the mindless adoption of opinions widespread in the environment. Because their content is always tinged with assessment and emotions, the stereotype may transmit both sympathy and approval, as well as prejudice, disapproval or antipathy (Smolski et al., 1999) and therefore constitute value judgements (Kotler et al., 1999). This is a kind of historical scheme, in large part created and repeated by the media, literature or events and based on the behavior of individuals so expressive that their characteristics are assigned to others (Macrae, 1991). The risk of reality perception through the lense of stereotypes is associated with the fact that they are also a tool for gaining cognitive control over the social environment and that they reduce cognitive processes as far as to a complete freedom from thinking (Łukaszewski \& Weigl, 2001). Stereotypes construct and constitute the social universum (Berger \& Luckmann, 2010).

The functions of stereotypes may be cognitive (expressed in the tendency to simplification and economization through selection and reducing information overload), adaptive (for quick orientation in the world, facilitating prediction of other people's behavior and selection of the most appropriate behavior), social (involving the defense and strengthening of the values accepted by a given community) and emotional (which implies a rationalization of hostile attitudes and aggression against different groups and justifying a higher sense of value and self-assessment of our own group) (Gawarkiewicz, 2011; Ruble \& Zhang, 2013). These functions enable (Budyta-Budzyńska, 2010):

- organization of the social world image - when 
certain categories are separated within the social reality, each encountered individual belonging to a particular category is perceived through the characteristics of that category (Tajfel, 1981; Tajfel \& Turner, 1986),

- creation and preservation of one's image and our own group - by indicating negative characteristics of others we boost our self-esteem and justify our own status,

- rationalization of prejudice and excuse ofor discrimination - we do not like certain people because they belong to groups undeserving sympathy, viewed through a negative stereotype;

- determining the conditions of social balance rules of discrete exclusion, acceptance and tolerance,

- creation and strengthening of national identity in the group - using national stereotypes of foreign groups, own national identity is built on the principle of the opposition.

The concept of national stereotype is closely linked with the image of a nation. Sometimes these terms are even used interchangeably, which is not correct because of their conotative and denotative scope. National stereotype is a narrower concept which relates to a set of personal attributes in semantic memory associated with the name of a nation (Gorbaniuk, 2009). National stereotypes can be defined as shared beliefs about the characteristics of a representative of a particular nation (Terracciano et al., 2005). Thinking about other nations most people would probably say that, for example, the Americans really cherish financial success, while for the Japanese - their attachment to tradition and social harmony are important and for the Scandinavians honesty and modesty (Lönnqvist et al., 2012).

In the twentieth century, there was the view that national stereotypes, similar to gender (Swim, 1994), race (McCauley \& Stitt, 1978; Ryan, 2002; Jussim, 2012) or age stereotypes (Costa et al., 2001; Chan et al., 2012) include a "grain of truth" (Allport, 1978/1954; Brigham, 1971) but recent results studies do not seem to confirm that (Terracciano et al., 2005; Lönnqvist et al., 2012; McCrae et al., 2013) and there is a view that the stereotypes related to perception of different nations do not reflect the real truth about these nations.

\section{RESEARCH METHODS}

The aim of the study was to determine whether the Podlasie entrepreneurs think about neighboring nations (Belarusian, Lithuanian, Ukrainian and Russian) in a stereotypical way (ascribing to them certain negative characteristics) and if it affects in any way the decision about cooperation.

Quantitative research using a questionnaire was chosen due to the necessity to reach a large number of respondents (Babbie, 2005; Dyduch, 2011). The questionnaire was anonimous in order to obtain more sincere answers (Sztumpski, 2010). The pilot study was carried-out on the turn of 2013 and 2014.

The main part focuses on the negative characteristics, potentially discouraging cooperation. 24 features were selected: backwardness, dishonesty, indiscipline, lack of self-confidence, lack of creativity, lack of perspective thinking, lack of innovativeness, excessive belay, impatience, poverty, greed, avarice, laziness, cunning, prone to theft, resort to violence, distrust, keeping promises, vindictiveness, falsity, hypocrisy, lack of communication, lack of standards of behavior and maladjustment to Polish standards of behavior. These features were extracted based on a critical analysis of the literature with particular emphasis on J. Błuszkowski's publication.

Respondents were asked to decide to what extent particular characteristic applied to the Russians, Belarusians, Lithuanians and Ukrainians (on a scale of 1 to 5 , where 1 - strongly disagree, 2 - disagree, 3 - neither agree, nor disagree, 4 - agree, 5 - strongly agree). At the same time the respondents decided about the extent to which a particular feature is important to them when making decisions about business cooperation (on a scale of 1 to 5, where: 1 - negligible feature; 2 - unimportant feature; 3 - feature of an average importance; 4 -important feature; 5 - very important feature) and whether any of these features exclude cooperation with a supplier, customer or cooperator.

Tabular data presentation and descriptive statistics proved to be useful to analyze the results. Thanks to them the following was specified: how the individual categories distributed in the research sample and what was the relation of the answers given to a specific variant to all of the answers.

\section{CHARACTERISTICS OF THE RESEARCH SAMPLE}

The research was carried out on a sample of 200 Podlasie companies. Random selection was used in 
the sample, a condition for participation in the study was to have the headquarters in the province of Podlasie. The vast majority of the studied companies belonged to the group of microenterprises, only slightly more than $1 / 3$ of the enterprises employed more than 9 persons, as illustrated in figure 1 .

The period of company activity on the market, in the vast majority, exceeded five years, only a few companies were on the market less than a year, which is illustrated by figure 2 .

The studied companies in a dominant part declared their business activity on the local market $-32 \%$, but

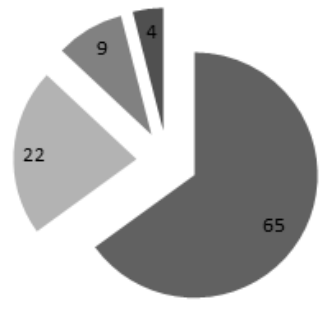

\section{- 0-9 employees \\ =10-49 employees \\ 50-249 employees \\ more than 249 employees}

Fig. 1. Structure of the studied companies by number of employees [\%]

Source: own study based on the research.

up to a quarter of the studied companies operated on the international market (Fig. 3), which is caused most likely by location of the Podlaskie region in close proximity to other countries.

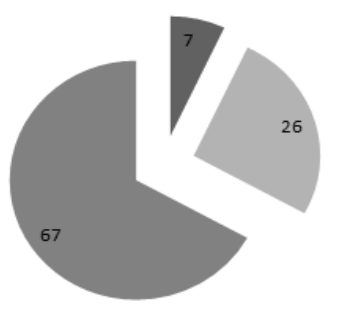

- less than a year

=1-5 years

more than 5 years

Fig. 2. Structure of the studied companies by the period of business activity on the market [\%]

Source: own study based on the research.

The important issue from the point of view of the object of study was also cooperation with Lithuania, Ukraine, Belarus and Russia (past, current, and declared in a perspective of next 3 years), which is illustrated in Fig. 4.

Chart analysis leads to the conclusion that most companies (1/4) declared its cooperation with Ukraine and it is the only country where you can see

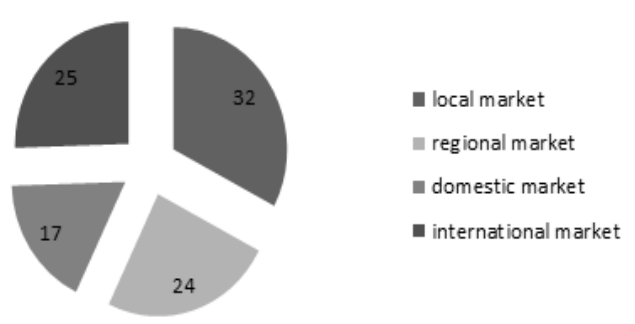

Fig. 3. Structure of the studied companies by the area of business activity [\%]

Source: own study based on the research.

a clear upward trend (however, it should be reminded that the survey was carried-out on the turn of the years 2013/2014 when Ukraine's situation in the international arena was different). For other countries, there was a slight decrease in co-operation as compared to the past, but at the same time declarations regarding future cooperation were optimistic in relation to all the neighboring countries.

When the continuity of the declared cooperation in the past, the present and the nearest future is analysed the greatest loyalty to Lithuania can be noticed. $22 \%$ of studied companies cooperated and cooperates with the Lithuanians and $23 \%$ work and intend to work with them in the future. For other countries, similar declarations were made by fewer respondents - the least of companies maintained continuity of cooperation with Ukraine, which is illustrated in Fig. 5.

\section{ANALYSIS OF THE RESEARCH RESULTS}

When the degree of importance of different characteristics significant for starting business cooperation was analysed, it was noticed that the majority of them (54\%) were considered to be of high importance (Tab. 1). The respondents considered studied the following characteristics: dishonesty, prone to theft, resort to violence, not keeping promises, vindictiveness, falsity and lack of communication, whereas important were: backwardness, lack of discipline, lack of perspective thinking, lack of innovativeness, greed, laziness, cunning and hypocrisy. Other characteristics were considered to be of moderate importance, none of them has been evaluated as unimportant or irrelevant when starting cooperation.

Respondents also declared whether certain characteristics preclude starting any business 


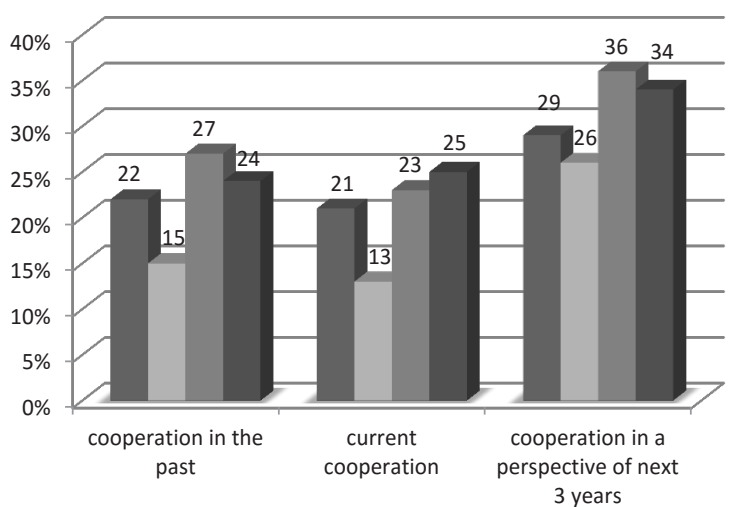

Fig. 4. Cooperation with Russia, Lithuania, Belarus and Ukraine in the past, present and in the nearest future [\%]

Source: own study based on the research.

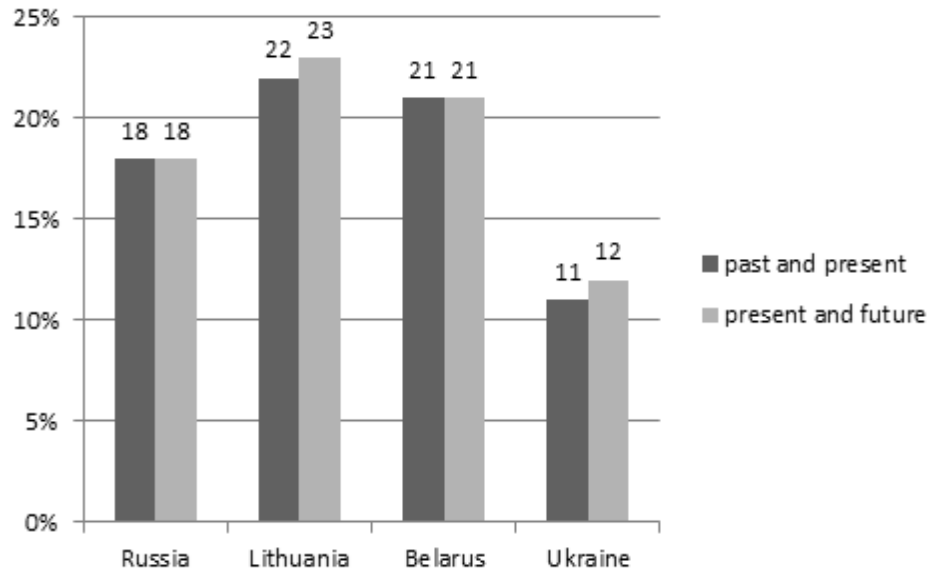

Fig 5. Percentage of respondents that maintain continuity of cooperation with Russia, Lithuania, Belarus and Ukraine [\%]

Source: own study based on the research.

cooperation (in regard to a supplier, customer or a cooperator). Despite indicating many characteristics as essential when starting business cooperation, only a few have been identified as preventing cooperation. Two characteristics: dishonesty and prone to theft exclude cooperation in regard to a supplier, a customer and a cooperator; not keeping promises prevent starting cooperation with a supplier and a cooperator, but does not apply to cooperation with a client; while cunning makes it impossible to cooperate with a client. Other characteristics considered at least important in making decisions about cooperation did not determine its exclusion.

The survey also asked if the aforementioned traits characterise the neighboring nations. This is illustrated in table 2 (although it is worth noting that the table includes only those traits for which the dominant answer was other than „neither agree nor disagree" in at least one country).

Analysis of the respondents' answers does not allow to draw the conclusion that the studied entrepreneurs from Podlasie are guided by negative national stereotypes in relation to neighbouring countries. None of the presented traits was indicated as definitely relating to a particular nationality. Similarly, none of the traits was indicated as definitely non-relating to a particular nationality. The majority of respondents marked the safest answer - „neither agree nor disagree".

In relation to the Russians seven characteristics were negated, in relation to the Belarusians two traits, and for Lithuanians eight characteristics - it can therefore be concluded that the respondents had no negative associations with these nations. The biggest neutrality can be seen in the evaluation of the Ukrainian nation the respondents could not agree with the presence or absence of any of the given characteristics.

It was also analyzed if there were differences in the perception of these nations through the lens of label traits - special attention was paid to the cooperation undertaken with individual countries, however, there was no difference observed in the dominant indications.

\section{CONCLUSIONS}

In the light of the literature stereotypes play a considerable role in shaping attitudes, opinions and decision making. Because creation of cross-border cooperation seems to be important for the development of Podlaskie Province the subject of research was the attitude of Podlasie entrepreneurs to the neighboring nations - the study concerned the negative traits that the Poles attribute to their eastern neighbors, and whether these traits can influence decisions about cooperation.

The results of the study proved to be quite optimistic. Comparing the gathered opinions with the research carried out by Błuszkowski (2005), the opinions perception of other nationalities across the 
Tab. 1. Degree of importance of different characteristics significant to start business cooperation (by analysis of the dominant responses)

\begin{tabular}{|l|l|l|}
\hline \multicolumn{1}{|c|}{ MediuM } & \multicolumn{1}{|c|}{ HIGH } & VERY HIGH \\
\hline lack of self-confidence & backwardness & resort to violence \\
\hline lack of creativity & indiscipline & prone to theft \\
\hline excessive belay & lack of innovativeness & dishonesty \\
\hline impatience & lack of perspective thinking & not keeping promises \\
\hline poverty & greed & vindictiveness \\
\hline avarice & laziness & falsity \\
\hline distrust & cunning & lack of communication \\
\hline lack of standards of behavior & hypocrisy & \\
\hline $\begin{array}{l}\text { maladjustment to Polish standards of behav- } \\
\text { ior }\end{array}$ & & \\
\hline
\end{tabular}

Source: own study based on the research.

Tab. 2. Respondents' opinion about the Russians, Belarussians, Lithuanians and Ukrainians (by analysis of the dominant responses)

\begin{tabular}{|l|c|c|c|c|}
\hline \multicolumn{1}{|c|}{ CHARACTERISTIC } & RUSSIANS & BELARUSSIANS & LITHUANIANS & UKRAINIANS \\
\hline backwardness & 3 & 3 & 2 & 3 \\
\hline dishonesty & 3 & 3 & 2 & 3 \\
\hline lack of discipline & 2 & 2 & 2 & 3 \\
\hline lack of self-confidence & 3 & 3 & 2 & 3 \\
\hline lack of creativity & 2 & 3 & 2 & 3 \\
\hline lack of perspective thinking & 2 & 3 & 3 & 3 \\
\hline lack of innovativeness & 2 & 3 & 2 & 3 \\
\hline poverty & 2 & 4 & 2 & 3 \\
\hline lack of communication & 2 & 2 & 2 & 3 \\
\hline lack of standards of behaviour & 2 & 3 & 2 & 3 \\
\hline
\end{tabular}

Source: own study based on the research (1 - strongly disagree, 2 - disagree, 3 - neither agree, nor disagree, 4 - agree, 5-strongly agree).

Eastern border by Poles from Podlaskie Province are more neutral (according to Błuszkowski's researches). Referring to the traits which were studied in both cases, Błuszkowki's study showed that all four countries are perceived as poor and backward. In addition, the Russians, Belarusians and Ukrainians are seen as lazy and undisciplined, and the Russians and Ukrainians as dishonest.

The differences in perception may have various causes. Primarily, the presented research was merely a pilot study and the sample cannot be considered representative, while Błuszkowski's research was carried out on a broader and more diverse sample, which is of great importance (Rogers \& Wood, 2010), and the respondents were not only people who have (or may have) business contacts with representatives of the studied nations. In addition, over the years opinions of the Poles may have changed.
Another reason could be the reluctance of the respondents to disclose their true attitudes due to the fact that their task was to respond only to negative traits (it was done on purpose - because of the respondents' unwillingness to fill in extensive questionnaires the focus was on the negative traits which might reduce willingness to start or maintain cooperation).

In conclusion, in the light of the pilot study the stereotypes referring the perception of listed nations do not seem to be a major barrier in starting crossborder cooperation because, although the respondents declared that the occurrence of specified traits is an important factor for them to start cooperation, they did not notice these traits in their Eastern neighbours. 


\section{LITERATURE}

Allport, G. W. (1954). The nature of prejudice. Massachusetts, USA: Addison-Wesley Reading.

Allport, G. W. (1978/1954). The nature of prejudice (25th anniversary ed.). New York, USA: Basic Books.

Aronson, E., Wilson, T. D., \& Akert, R. M. (1997). Psychologia społeczna. Serce i umyst [Social psychology. The heart and the mind]. Poznań, Poland: Zysk i S-ka.

Babbie, E. (2005). Badania społeczne $w$ praktyce [Social research in practice]. Warszawa, Poland: Wydawnictwo Naukowe PWN.

Berger, P. L., \& Luckmann T. (2010). Społeczne tworzenie rzeczywistości. Traktat $z$ socjologii wiedzy [The creation of social reality. The treaty of sociology of knowledge]. Warszawa, Poland: Wydawnictwo Naukowe PWN.

Biernat, M., \& Crandall, C. S. (1996). Creating stereotypes and capturing their content. European Journal of Social Psychology, 26, 867-898.

Błuszkowski, J. (2005). Stereotypy a tożsamość narodowa [Stereotypes and national identily]. Warszawa, Poland: Dom Wydawniczy Elipsa.

Brigham, J. C. (1971). Ethnic stereotypes. Psychological Bulletin, 76, 15-38.

Budyta-Budzyńska, M. (2010). Socjologia narodu $i$ konfliktów etnicznych [Sociology of the nation and ethnic conflicts]. Warszawa, Poland: Wydawnictwo Naukowe PWN.

Chan, W., McCrae, R. R., De Fruyt, F., Jussim, L., Lockenhoff, C. E., \& De Bolle, M. (2012). Stereotypes of age differences in personality traits: Universal and accurate? Journal of Personality and Social Psychology, 103, 1050-1066.

Costa, P. T. Jr., Terracciano, A., \& McCrae, R. R. (2001). Gender differences in personality traits across cultures: Robust and surprising findings. Journal of Personality and Social Psychology, 81, 322-331.

Coutant, D., Worchel, S., Bar-Tal, D., \& van Raalten, J. (2001). A multidimensional examination of the "Stereotype" concept: A developmental approach. International Journal of Intercultural Relations, 35, 92-110.

Dyduch, W. (2011). Ilościowe badania i operacjonalizacja zjawisk w naukach o zarządzaniu [Quantitative research and operalization of phenomena in management science]. In W. Czakon (Eds.), Podstawy metodologii badań $w$ naukach o zarządzaniu [The basic of research methodology in management science]. Warszawa, Poland: Wolters Kluwer Business.

Fiske, S. T. (1998). Stereotyping, prejudice and discrimination. In D. T. Gilbert, S. T. Fiske, \& G. Lindzey (Eds.), The handbook of social psychology (pp. 357-411). Boston, USA: McGraw-Hill.

Ford, T. E., \& Stangor, C. (1992). The role of diagnosticity in stereotype formation: Perceiving group means and variances. Journal of Personality and Social Psychology, 63, 356-367.

Gawarkiewicz, R. (2011). Komunikacja międzykulturowa a stereotypy. Polacy - Niemcy - Rosjanie [Intercultural
Communications and stereotypes. Poles - Germany Russians]. Szczecin, Poland: Uniwersytet Szczeciński.

Gorbaniuk, O. (2009). Wizerunek Niemiec i narodu niemieckiego wśród polskiej młodzieży [The image of germany and German people among Polish youth]. In O. Gorbaniuk, \& B. Jóźwik (Eds.), Społecznogospodarcze aspekty współpracy Polsko-Niemieckiej [Socioeconomic aspect of Polish-German cooperation]. Lublin, Poland: KUL.

Gurgul, H., \& Lach, Ł. (2014). Globalization and economic growth: Evidence from two decades of transition in CEE. Economic Modelling, 36, 99-107.

Hill, R. (2004). My Europejczycy [We Europeans]. Warszawa, Poland: Wydawnictwo Czarna Owca.

Hilton, J. L., \& Hippel, W. (1996). Stereotypes. Annual Review of Psychology, 47, 237-271.

Jussim, L. J. (2012). Social perception and social reality: Why accuracy dominates bias and self-fulfilling prophecy. New York, USA: Oxford University Press.

Kofta, M., \& Sędek, G. (1999). Stereotypy duszy grupowej a postawy wobec innych: wyniki badań sondażowych [Soul group stereotypes and attitudes towards others: the results of surveys]. In B. Wojciszke, \& M. Jarymowicz (Eds.), Psychologia rozumienia zjawisk społecznych [Psychology understanding of social phenomena]. Warszawa-Łódź, Poland: Wydawnictwo Naukowe PWN.

Kotler, P., Asplund, Ch., Rein, I., \& Haider, D. (1999). Marketing Places Europe. New York, USA: Financial Times Prentice Hall.

Kurcz, I. (1994). Zmienność i nieuchronność stereotypów [Volatility and the inevitability of stereotypes]. Warszawa, Poland: Wydawnictwo Instytutu Psychologii PAN.

Lippmann, W. (1965). Public Opinion. New York, USA: The Free Press.

Lönnqvist, J. E., Yijälä, A., Jasinskaja-Lahtib, I., \& Verkasalo M. (2012). Accuracy and contrast in national value stereotypes - A Case study using Ingrian-Finns as bicultural experts. International Journal of Intercultural Relations, 36, 271-278.

Łukaszewski, W., \& Weigl, B. (2001). Stereotyp stereotypu czy prywatna koncepcja natury ludzkiej? [The stereotype of stereotype or private conception of human nature?] In M. Kofta, \& A. Jasińska-Kania (Eds.), Stereotypy $i$ uprzedzenia: uwarunkowania psychologiczne i kulturowe [Stereotypes and prejudices: the psychological and cultural factors]. Warszawa, Poland: Wydawnictwo Naukowe Scholar.

Macrae, C. N., Stangor, Ch., \& Hewstone, M. (1991). Stereotypy i uprzedzenia [Stereotypes and prejudices]. Gdańsk, Poland: Gdańskie Wydawnictwo Psychologiczne.

Martin, C. L. (1987). A ratio measure of sex stereotyping. Journal of Personality and Social Psychology, 52, 489499.

McCauley, C., \& Stitt, C. L. (1978). An individual and quantitative measure of stereotypes. Journal of Personality and Social Psychology, 36, 929-940.

McCrae, R. R. et al. (2013). The inaccuracy of national character stereotypes. Journal of Research in Personality, 47, 831-842. 
Mierosławska, A. (2004). Czynniki aktywizujące i hamujące rozwój współpracy transgranicznej [The factors activating and inhibiting the development of crossborder cooperation]. Samorzad Terytorialny, 3, 4258.

Pisarenko, S. (1998). Bariery społeczno-gospodarcze ukraińsko-polskiej współpracy trans granicznej [Socio-economic bariers in Ukrainian-Polish crossborder cooperation]. In J. Kitowski (Eds.), Czynniki $i$ bariery regionalnej współpracy transgranicznej -próba syntezy [Factors and barriers to regional cross-border cooperation - an attempt synthesis], (pp. 39-40). Rzeszów, Poland: Rozprawy i Monografie Wydziału Ekonomicznego.

Qiu, L. D. (2010). Cross-border mergers and strategic alliance. European Economic Review, 54, 818-831.

Reszke, I. (1998). Stereotypy prywatnych przedsiębiorców $w$ Polsce [Stereotypes about private entrepreneurs in Poland]. Warszawa, Poland: Wydawnictwo IFiS PAN.

Rogers, K. H., \& Wood, D. (2010). Accuracy of United States regional personality stereotypes. Journal of Research in Personality, 44, 704-713.

Ruble, R. A., \& Zhang Y. B. (2013). Stereotypes of Chinese International students held by Americans. International Journal of Intercultural Relations, 37, 202-211.

Ryan, C. S. (2002). Stereotype accuracy. European Review of Social Psychology, 13, 75-109.

Smolski, R., Smolski, M., \& Stadmüller, E. H. (Eds.). (1999). Słownik Encyklopedyczny Edukacja Obywatelska [Encyclopedic Dictionary Civic Education]. Warszawa, Poland: Wydawnictwo Europa.

SOCLAB (2013). Samorzadowa i obywatelska współpraca transgraniczna $w$ województwie podlaskim [Local goverment and citizen cross-border cooperation in Podlaskie region]. Białystok, Poland: Laboratorium Badań i Opinii Społecznych.

Spencer-Rodgers, J. (2001). Consensual and individual stereotypic beliefs about international students among American host national. International Journal of Intercultural Relations, 25, 639-657.

Stephan, W. G., \& Stephan, C. W. (2007). Wywieranie wpływu przez grupy. Psychologia relacji [Influence by the group. Psychology of relationships]. Gdańsk, Poland: Gdańskie Wydawnictwo Psychologiczne.

Swim, J. K. (1994). Perceived versus meta-analytic effect sizes: An assessment of the accuracy of gender stereotypes. Journal of Personality and Social Psychology, 66, 21-36.

Sztumski, J. (2010). Wstep do metod i technik badań społecznych [Introduction to the methods and techniques of social research]. Katowice, Poland: Wydawnictwo „Śląsk”.

Tajfel, H. (1981). Human Groups and Social Categories: Studies in Social Psychology. Cambridge, Great Britain: Cambridge University Press.

Tajfel, H., \& Turner, J. C. (1986). The Social Identity Theory of Intergroup Behaviour. In S. Worchel, \& W. Austin (Eds.), The Psychology of Intergroup Relations. Chicago, USA: Nelson-Hall.

Terracciano, A. et al. (2005). National character does not reflect mean personality trait levels in 49 cultures.
Science, 310, 96-100. 